\title{
Peranan Wisdom terhadap Subjective Well-Being pada Dewasa Awal
}

\author{
Zahra Farida Intani ${ }^{1}, \mathcal{E}$ Aisah Indati ${ }^{2}$ \\ Fakultas Psikologi Universitas Gadjah Mada
}

\begin{abstract}
Subjective well-being is one of the topics of positive psychology studies related to one's quality of life, while wisdom is the highest ability that one can have from their life experiences. This study aimed to determine the contribution of wisdom on subjective wellbeing in early adulthood. The hypothesis proposed in this study was wisdom contributes positively toward subjective well-being in early adulthood. Participants of the study $(\mathrm{N}=158)$ were undergraduate students (female $=98$, male $=60$ ) who are working on their final project (thesis). Data was collected using Skala Kesejahteraan Subjektif developed by Utami and the adaptation of The Three Dimensional Wisdom Scale (3D-WS). Result showed that wisdom significantly predicted subjective well-being in positive direction.
\end{abstract}

Keyword: early adulthood; subjective well-being; wisdom

Abstrak. Subjective well-being adalah salah satu topik kajian psikologi positif yang berkaitan dengan kualitas hidup individu, sedangkan wisdom adalah kemampuan tertinggi yang bisa dimiliki individu dari pengalaman-pengalaman yang dihadapinya selama hidup. Penelitian ini bertujuan untuk mengetahui peran wisdom terhadap subjective well-being pada dewasa awal. Hipotesis yang diajukan adalah wisdom berpengaruh positif terhadap subjective well-being pada dewasa awal. Subjek penelitian $(N=158)$ merupakan mahasiswa $S 1$ (perempuan $=98$, laki-laki $=$ 60) yang sedang mengerjakan tugas akhir (skripsi). Skala yang digunakan dalam penelitian ini terdiri dari Skala Kesejahteraan Subjektif yang dikembangkan oleh Utami dan Skala Kebijaksanaan yang merupakan adaptasi dari The Three Dimensional Wisdom Scale (3D-WS). Analisis data menemukan bahwa variabel wisdom memberikan pengaruh positif yang signifikan terhadap subjective well-being pada dewasa awal. Berdasarkan hasil tersebut, dapat disimpulkan bahwa wisdom memberikan pengaruh positif terhadap subjective well-being.

Kata kunci: dewasa awal; subjective well-being; wisdom

Kajian mengenai psikologi positif semakin banyak dikembangkan dalam ranah Ilmu Psikologi. Pandangan psikologi positif mengajak manusia untuk melihat dari kaca-

${ }^{1}$ Korespondensi mengenai isi artikel ini dapat dilakukan melalui zahra.frida.i@mail.ugm.ac.id

${ }^{2}$ Atau melalui aisah.indati@gmail.com mata positif, bahwa manusia selalu memiliki potensi atau kekuatan untuk bangkit dari suatu keadaan yang membuat mereka tidak berdaya. Manusia mampu menentukan sendiri cara dirinya memandang kehidupan. Salah satu topik dalam psikologi positif adalah subjective well-being, yaitu evaluasi yang diberikan seseorang terhadap kehidupannya. Seseorang yang dikatakan memiliki 
subjective well-being tinggi yaitu seseorang yang memiliki kepuasan dalam hidupnya. Selain itu, mereka juga merasakan emosi positif seperti kegembiraan dan kasih sayang serta tidak adanya simptom depresif (Ardelt \& Edwards, 2015). Subjective wellbeing juga didefinisikan sebagai penilaian seseorang terhadap kehidupannya baik yang bersifat kognitif maupun afektif. Penilaian kognitif berkaitan dengan standar kepuasan hidup, sementara penilaian afektif berkaitan dengan seberapa sering seseorang mengalami mood dan emosi yang bersifat positif dan negatif (Andartyastuti, Maslihah, \& Chitidjah, 2015).

Kompleksitas permasalahan dalam hidup dewasa ini seperti permasalahan ekonomi, sosial, pendidikan, teknologi, dan moral membuat penilaian dan kepuasan indi-vidu akan hidupnya menjadi hal yang perlu ditelusuri. Manusia selalu menemui tan-tangan akan perubahan di setiap rentang perkembangan hidupnya. Selain tantangan yang datang dari lingkungan eksternal seperti ekspektasi atau harapan dari lingkungan, juga terdapat perubahan dari internal diri individu tersebut.

Pada masa dewasa awal, individu dihadapkan dengan dunia baru yang melihat-nya kini bukan lagi sebagai remaja, tapi sebagai seorang dewasa yang sudah mampu hidup mandiri dan bertanggung jawab. Masa dewasa awal adalah periode perkembangan manusia yang dimulai dari awal usia 20 sampai usia 30 tahun (Santrock, 2014). Periode ini adalah waktu bagi individu untuk membangun kemandirian, baik pribadi mau-pun ekonomi, mengejar karier, membangun sebuah keluarga, dan mengasuh anak-anak (Santrock, 2014).

Dewasa awal juga merupakan masa bagi individu untuk mandiri baik secara fisik maupun ekonomi. Di Indonesia, Badan
Pusat Statistik (2017) mencatat jumlah angkatan kerja pada Februari 2017 sebanyak 131,55 juta orang, dengan jumlah pengangguran sebanyak 7,01 juta orang. Reivich dan Shatte (2002) menyebutkan bahwa individu yang belum memiliki pekerjaan memiliki beban secara psikologis seperti perasaan cemas serta ketakutan akan kegagalan. Reaksi ini kemudian menimbulkan stres, kecemasan, dan ketakutan. Kholidah dan Alsa (2012) menemukan sumber stres pada individu usia dewasa awal khususnya mahasiswa, yaitu diantaranya berupa ketatnya persaingan dalam mencapai prestasi, manajemen diri yang kurang baik, adaptasi dengan lingkungan baru, tuntutan kehidupan baik dari dalam maupun luar kampus, dan desakan untuk menyelesaikan studi tepat waktu. Gunawati, Hartati, dan Listiara (2006) juga menyatakan bahwa dalam proses penyelesaian tugas akhir pun, tidak jarang individu mengalami stres dan perasaan negatif. Hal ini juga didukung oleh penelitian yang dilakukan Rohmah (2006) yang menemukan bahwa 39,2\% mahasiswa tingkat akhir mengalami stres.

Individu usia dewasa awal yang masih menempuh pendidikan tinggi menghadapi ekspektasi dari orang-orang di sekitarnya mengenai karier yang kelak dijalaninya. Kenyataan akan tidak mudahnya mencari pekerjaan justru membuat sebagian individu melakukan penundaan penyelesaian studinya. Hammer dan Ferrari (dalam Klassen, Krawchuck, \& Rajani, 2008) menemukan sebanyak 20\% individu usia dewasa mengalami penundaan kronis untuk tugas-tugas sehari-hari, sementara untuk prokrastinasi akademik pada mahasiswa diperkirakan berada pada tingkat 70-95\%. Penundaan terhadap satu tahapan dalam tugas perkembangan dapat memengaruhi tahapan tugas perkembangan lainnya. Indi- 
vidu yang merasakan stres namun tidak segera menyelesaikan tugas perkembangannya mempunyai kemungkinan memiliki subjective well-being rendah.

Beberapa penelitian telah menemukan faktor-faktor yang memengaruhi subjective well-being, diantaranya faktor demografis, kepribadian, pendidikan, religiusitas, dan wisdom. Wisdom adalah kemampuan individu dalam menerima dan memahami makna dari segala peristiwa yang terjadi dalam hidupnya (Ardelt \& Edwards, 2015). Individu yang mampu beradaptasi dengan baik terhadap perubahan dapat menumbuhkan penilaian positif terhadap diri sendiri maupun terhadap hidupnya. Meskipun banyak tantangan yang mengarahkan pada kondisi stres, tidak sedikit pula individu yang mampu menghadapinya dan merasa bahagia dengan hidupnya. Ardelt dan Edwards (2015) mengatakan bahwa individu yang bijaksana mampu mempertahankan kesadaran akan kemampuannya menguasai sesuatu (sense of mastery), tujuan hidup, dan subjective well-being, bahkan jika individu tersebut berada dalam kondisi atau situasi yang buruk sekalipun.

Randall dan Kenyon (dalam Ardelt \& Edwards, 2015) mengemukakan bahwa karakteristik dasar kebijaksanaan (wisdom) adalah penerimaan dan kemampuan untuk menentukan makna dari penderitaan tanpa pelarian dan keputusasaan. Wisdom memungkinkan seseorang untuk mengambil keputusan yang paling tepat dan efektif untuk menghadapi berbagai situasi kehidupan yang sulit, memudahkan individu dalam memecahkan permasalahan, dan beradaptasi dengan lingkungan (Arzeen, Haque, \& Arzeen, 2013). Individu yang bijaksana memiliki kepuasan hidup yang tinggi karena kemampuannya menerima tantangan kehidupan dan mengambil makna dari hal tersebut.

Kemampuan individu yang bijaksana dalam menggunakan berbagai perspektif memungkinkan mereka untuk membangun solusi alternatif. Hal ini dapat meningkatkan kemampuan problem solving individu untuk koping yang lebih efektif dalam penyelesaian masalah kehidupan (Etezadi \& Pushkar, 2013). Ketika penyelesaian masalah tidak berjalan dengan baik, komitmen untuk berkembang yang dimiliki individu yang bijaksana dan kemampuannya untuk melihat hal positif dari berbagai kesulitan dapat dimanifestasikan sebagai reinterpretasi positif dari stressful life events (Etezadi \& Pushkar, 2013). Individu yang bijaksana melihat kegagalan sebagai peluang untuk belajar dari pengalaman, menemukan makna dan tujuan hidup, serta hidup dalam perasaan positif. Individu yang bijaksana juga memiliki pemahaman yang mendalam dalam kehidupan (Ardelt, 2015). Mereka dapat menerima ketidakpastian dalam hidup dengan tenang, yang memungkinkan individu untuk mengurangi stres dan mempromosikan subjective well-being.

Wisdom sendiri telah diketahui sebagai prediktor dari subjective well-being pada individu lanjut usia (Ardelt \& Edwards, 2015), namun belum ada penelitian yang meneliti hubungan wisdom dengan subjective well-being pada individu yang masuk pada fase dewasa awal. Meski demikian, Hyeyoung (2013) menyatakan bahwa individu yang sudah menemukan identitas diri besar kemungkinan dapat menunjukkan dimensi kebijaksanaan karena telah menjelajahi diri dari proses pencarian identitas pada masa remaja. Hal ini menjelaskan bahwa masa dewasa awal adalah salah satu masa penting di mana individu diprediksi sudah mampu menunjukkan 
dimensi kebijaksanaan dan memperlihatkan penilaian positif dari kehidupannya. Berdasarkan pemaparan di atas, penelitian tentang pengaruh wisdom terhadap subjective wellbeing pada dewasa awal menjadi penting dan menarik untuk dilakukan.

\section{Metode}

Subjek dalam penelitian ini adalah individu usia dewasa awal yang merupakan mahasiswa S1, berjenis kelamin laki-laki maupun perempuan, berusia 20-25 tahun, dan sedang mengerjakan tugas akhir (skripsi). Jumlah subjek dalam penelitian ini berjumlah 158 orang dengan rincian subjek perempuan berjumlah 98 orang dan subjek laki-laki berusia 60 orang. Rata-rata subjek berusia 22 tahun.

Alat pengumpul data yang digunakan dalam penelitian ini berupa skala. Terdapat dua skala yang digunakan, yaitu Skala Kesejahteraan Subjektif milik Utami (2010) dan skala adaptasi The Three Dimensional Wisdom Scale (3D-WS) milik Ardelt (2003) yang dalam penelitian ini disebut dengan Skala Kebijaksanaan. Skala Kesejahteraan Subjektif terdiri dari tiga subskala, yaitu Subskala Afek Positif, Subskala Afek Negatif, dan Subskala Kepuasan Hidup. Ketiga sub-skala ini perlu dikonversikan ke dalam z-score agar terstandar dan dapat dikalkulasikan menjadi satu skor Skala Kesejahteraan Subjektif.

Sebelum dilakukan pengambilan data, dilakukan uji coba skala terlebih dahulu untuk mengetahui reliabilitas dan validitas kedua skala yang dipakai. Setelah dilakukan ujicoba, ditemukan bahwa Subskala Afek Positif memiliki indeks daya beda yang berkisar antara 0,336-0,669 dengan koefisien reliabilitas alpha Cronbach sebesar 0,899. Subskala Afek negatif memiliki indeks daya beda yang berkisar antara 0,313 sampai dengan 0,809 dengan koefisien alpha Cronbach 0,941. Demikian pula dengan Subskala Kepuasan Hidup yang memiliki koefisien reliabilitas 0,924 dengan koefisien korelasi aitem total yang berkisar antara 0,300 hingga 0,688. Skala Kebijaksanaan memiliki koefisien alpha Cronbach sebesar 0,853 dengan indeks daya beda yang bergerak dari 0,045 sampai 0,556.

Pengambilan data dilakukan di Fakultas Farmasi Universitas Gadjah Mada (UGM), Fakultas Hukum UGM, Fakultas Psikologi UGM, Fakultas Matematika dan Ilmu Pengetahuan Alam UGM, Fakultas Teknik UGM, serta di lingkungan sekitar peneliti yang dianggap sesuai dengan kriteria subjek penelitian dengan teknik snowball sampling. Metode analisis yang digunakan dalam penelitian ini adalah analisi regresi linier sederhana.

\section{Hasil}

Hipotesis yang diajukan dalam penelitian ini adalah wisdom berpengaruh positif terhadap subjective well-being pada dewasa awal. Pengujian hipotesis pada penelitian ini dilakukan dengan menggunakan teknik analisis regresi linier sederhana. Sebelum melakukan uji hipotesis, perlu dilakukan uji asumsi terlebih dahulu. Dua syarat uji asumsi yang harus dilakukan adalah uji normalitas dan uji linieritas.

Pada penelitian ini, uji normalitas dilakukan dengan menggunakan metode uji One-Sample Kolmogrov-Smirnov Test. Taraf signifikansi variabel subjective well being berada pada taraf 0,434 dan taraf signifikansi variabel wisdom berada pada taraf 0,687 sehingga dapat dikatakan sebaran atau distribusi data kedua variabel tersebut normal karena memiliki taraf signifikansi $p>0,05$. 
Berdasarkan pengujian linieritas, variabel subjective well-being dan wisdom dalam penelitian ini mempunyai taraf signifikansi linearity $p<0,05$. Selain itu, kedua variabel tersebut mempunyai signifikansi deviation from linearity sebesar 0,752 $(p>0,05)$ sehingga dapat dikatakan jika data dan kedua variabel dalam penelitian ini normal dan linier.

Setelah kedua syarat uji asumsi terpenuhi, maka selanjutnya dapat dilakukan pengujian hipotesis. Hasil analisis regresi linier sederhana menunjukkan nilai $b$ sebesar 0,328. Hasil tersebut menunjukkan bahwa wisdom berperan terhadap subjective well-being pada dewasa awal. Hasil analisis juga me-nunjukkan koefisien determinasi $R^{2}$ sebesar 0,108, yang memiliki arti bahwa variabel wisdom memberikan sumbangan efektif pada subjective well-being sebanyak $10,8 \%(p<0,001)$. Nilai sumbangan efektif mengandung arti bahwa wisdom memiliki peranan dalam mem-prediksi subjective wellbeing pada dewasa awal, sedangkan 89,2\% lainnya merupakan sumbangan variabel lain yang tidak diteliti dalam penelitian ini. Hasil analisis linier sederhana juga menunjukkan hasil nilai $F=18,869(p<0,01)$, maka dapat disimpulkan bahwa wisdom memiliki hubungan yang signifikan terhadap subjective well-being.

Peneliti membuat analisis tambahan untuk melihat perbedaan subjective well-being terhadap jenis kelamin dan usia subjek penelitian. Untuk mengetahui gambaran subjective well-being subjek berdasarkan jenis kelamin, dilakukan uji Independent sample ttest, sedangkan untuk mengetahui perbedaan subjective well-being pada rentang usia subjek dilakukan dengan menggunakan uji One-Way ANOVA. Berdasarkan hasil analisis pada subjective well-being jika ditinjau dari faktor demografis subjek penelitian yang meru-pakan individu usia dewasa awal, ditun-jukkan angka $p=0,029(p<0,05)$ untuk faktor jenis kelamin dan $p=0,958(p>$ $0,05)$ untuk faktor usia. Hasil tersebut menunjukkan bahwa ada perbedaan subjective well-being antara subjek laki-laki dan perempuan, dan tidak ada perbedaan yang signifikan pada subjective well-being apabila ditinjau dari usia subjek.

\section{Diskusi}

Subjective well-being menggambarkan bagaimana seseorang merasa puas akan apa yang terjadi dalam hidupnya, memiliki perasaan positif, dan tidak mudah merasakan emosi negatif. Subjective well-being adalah capaian yang diinginkan setiap individu dalam hidupnya, tak terkecuali untuk dewasa awal. Individu yang memasuki usia dewasa awal dihadapkan dengan berbagai macam tantangan terkait penyesuaian baik dengan diri sendiri maupun dengan tuntutan lingkungan. Subjek penelitian ini adalah individu usia dewasa awal yang merupakan maha-siswa semester akhir dan sedang mengerjakan skripsi. Bagi sebagian orang, skripsi dapat dimaknai sebagai stressor bagi mahasiswa semester akhir yang sedang menjalaninya (Mariyanti, 2013). Berbagai respon terhadap stressor yang ditunjukkan individu inilah yang dapat memengaruhi kondisi subjective well-being seseorang.

Hipotesis yang diajukan dalam penelitian ini adalah wisdom memiliki pengaruh positif terhadap subjective wellbeing individu pada usia dewasa awal. Berdasarkan analisis regresi yang telah dilakukan, diketahui bahwa wisdom memberikan sum-bangan sebesar 10,8\% terhadap subjective well-being pada dewasa awal, sementara sebanyak 89,2\% lainnya merupakan sumbangan dari variabel lain yang tidak 
diteliti pada penelitian ini. Hasil penelitian ini sejalan dengan hasil penelitian yang dilakukan Ardelt dan Edwards (2015) yang menyatakan bahwa wisdom berperan sebagai faktor yang memengaruhi subjective wellbeing. Individu yang bijaksana merasakan kepuasan dan pemenuhan terhadap hidupnya, sehingga hal tersebut dapat memengaruhi subjective well-being seseorang (Ardelt, 2000).

Hasil analisis juga menunjukkan hubungan positif yang signifikan antara wisdom dengan subjective well-being pada dewasa awal. Hasil tersebut dapat dimaknai bahwa semakin tinggi wisdom, maka semakin tinggi pula subjective well-being individu. Hal ini sesuai dengan penelitian Arzeen et al. (2013) yang menyatakan bahwa terdapat hubungan yang signifikan dan positif antara wisdom dengan subjective well-being. Individu yang bijaksana diketahui mampu mempertahankan subjective well-being-nya, bahkan jika individu tersebut berada dalam kondisi atau situasi yang buruk sekalipun (Ardelt \& Edwards, 2015).

Pada masa dewasa awal, individu dihadapkan pada tantangan hidup yang baru. Individu yang bijaksana mampu melihat tantangan sebagai peluang untuk belajar dari pengalaman, menemukan makna dan tujuan hidup, serta hidup dalam perasaan positif (Ardelt \& Edwards, 2015). Berdasarkan hal tersebut, dapat dikatakan bahwa subjek yang berada pada usia dewasa awal dan sedang mengerjakan tugas akhir mampu mengambil makna dan melihat tantangannya tersebut sebagai peluang untuk belajar. Hal ini lah yang dapat meningkatkan evaluasi individu baik secara kognitif maupun afektif terhadap hidupnya. Pengalaman individu menghadapi berbagai perubahan dari masa remaja hingga masa dewasa awal, tantangan dalam dunia pendidikan, berbagai situasi yang dihadapkan untuk dapat membuat keputusan dijadikan pelajaran untuk bersikap lebih baik di masa depan. Hal ini sesuai dengan penelitian Eddington dan Shuman (2005) yang menyatakan bahwa pengalaman hidup dan sikap atau respon individu dalam meng-hadapi perubahan yang terjadi dalam hidup-nya juga merupakan faktor yang berpengaruh terhadap subjective well-being.

Hasil analisis terhadap subjek penelitian mengenai tingkat subjective well-being menunjukkan bahwa sebanyak 59,5\% subjek berada dalam kategori sedang dan 19\% subjek masuk ke dalam kategori subjective well-being rendah. Hal ini dapat dipengaruhi oleh variabel lain yang tidak diteliti pada penelitian ini. Meski demikian, 20,3\% subjek masuk ke dalam kategori tinggi. Hal ini menunjukkan bahwa individu yang sedang dihadapkan dengan berbagai tugas perkembangan, salah satunya adalah menyelesaikan pendidikan, tetap mampu mempertahankan subjective well-being-nya.

Paparan stressor berupa skripsi bisa menjadi salah satu stressor dalam fase dewasa awal. Bagaimana individu merespon berbagai stressor dalam kehidupan turut berkontribusi pada subjective well-being-nya. Pada masa dewasa awal, terdapat pula tantangan besar berupa penyesuaian diri untuk menanggalkan peran sebagai remaja menjadi seorang yang dewasa. Hasil penelitian terhadap dewasa awal ini menunjukkan bahwa meskipun individu berada pada kondisi yang penuh tekanan dan emosi negatif karena skripsi dan tugas perkembangan lainnya, seseorang tetap bisa mempertahankan subjective well-being-nya. Hal ini memberikan pandangan baru terhadap penelitian yang dilakukan oleh Richardson dan Pasupathi (2005) yang menyatakan bahwa pada masa remaja dan 
dewasa awal, karakteristik personal seperti emosi negatif, self-esteem yang rendah, kemampuan koping, dan regulasi emosi yang buruk berada pada masa-masa puncaknya. Hasil penelitian ini menunjukkan bahwa meskipun terdapat banyak tantangan dalam fase dewasa awal, individu tidak lantas selalu memiliki subjective well-being yang rendah.

Apabila ditinjau dari persebaran jenis kelamin, subjek dalam penelitian ini terdiri dari 60 laki-laki dan 98 perempuan. Analisis terhadap perbedaan subjective well-being antar jenis kelamin menunjukkan bahwa ada perbedaan subjective well-being antara perempuan dan laki-laki. Rerata perempuan lebih rendah dari laki-laki, sehingga dapat disimpulkan bahwa subjective well-being laki-laki lebih tinggi daripada perempuan dalam penelitian ini. Temuan ini sejalan dengan penelitian yang dilakukan oleh Lewis, Maltby, dan Day (2005) yang mengungkapkan bahwa laki-laki memiliki subjective well-being lebih tinggi dibandingkan perempuan. Hal ini mungkin dikarenakan perempuan lebih rentan terhadap stres apabila dibandingkan dengan laki-laki (Eddington \& Shuman, 2005).

Analisis terhadap perbedaan usia subjek menunjukkan bahwa tidak ada perbedaan yang signifikan pada subjective wellbeing apabila ditinjau dari variasi usia subjek. Hal ini mungkin dikarenakan subjek seluruhnya berada pada rentang usia dewasa awal sehingga perbedaan usia tidak terlalu signifikan. Staudinger dan Pasupathi (2003) percaya bahwa wisdom berkembang sejak masa remaja dan dewasa awal, meskipun pada masa ini banyak faktor lain yang juga bisa memengaruhi kondisi afek dan kepuasan hidup individu. Subjek pada penelitian ini seluruhnya telah matang secara kognitif, sehingga dapat mengguna- kan penalarannya sebagai modal dalam mengembangkan wisdom.

Individu yang bijaksana dapat memberikan penilaian yang tepat dalam memandang segala situasi dalam hidupnya (Ardelt, 2003). Maka dari itu, individu yang bijaksana mampu beradaptasi dan melakukan penyesuaian diri terhadap keadaan hidup yang berubah-ubah, salah satu contohnya apabila menghadapi beberapa tugas sekaligus maupun dihadapkan dengan tuntutan lingkungan. Kemampuan individu yang bijaksana dalam memahami kehidupan secara mendalam dan menerima ketidakpastian dalam hidup dapat mengurangi stres dan meningkatkan subjective well-being (Ardelt, 2015).

Bagi mahasiswa tingkat akhir, pertanyaan seputar kapan lulus, kapan bekerja, dan kapan menikah bisa menjadi beban tersendiri. Ketidakpastian dalam hidup perlu disadari dan diterima agar tidak menjadi momok bagi individu. Individu yang bijaksana mampu memahami kondisinya dan tetap menatap masa depan secara positif. Pengerjaan tugas akhir adalah salah satu bentuk usaha untuk tetap bertahan dalam melanjutkan langkah di masa depan. Individu usia dewasa awal yang memiliki wisdom tinggi mampu mempertahankan penilaian positif dan kondisi afek positifnya sehingga menghasilkan subjective well-being yang tinggi.

Selain memiliki pemahaman yang lebih mendalam tentang hidup, individu yang bijaksana juga mampu mengembangkan pemikiran reflektif dan dapat melihat fenomena dengan berbagai perspektif yang ada (Ardelt, 2003). Sebanyak 96 subjek atau $60,8 \%$ dari total subjek pada penelitian ini masuk dalam kategori tinggi pada variabel wisdom. Artinya, meskipun tahun-tahun terakhir sebagai mahasiswa kerap dianggap 
berat, individu mampu memaknainya dan tetap bersikap positif. Proyeksi dari peristiwa yang tidak menyenangkan dalam hidup seringkali menimbulkan perasaan negatif yang kemudian memengaruhi evaluasi kognitifnya atas kepuasan hidup, namun individu yang bijaksana mampu menerima realitas seperti apa adanya tanpa bereaksi atau merespon negatif terhadap peristiwa yang tidak menyenangkan tersebut (Ardelt, 2000). Hal ini menunjukkan bahwa mayoritas subjek mampu merespon positif terhadap berbagai tantangan yang dihadapi dalam hidupnya dan merasa puas akan apa yang telah dicapainya.

Aspek afektif dari wisdom juga memberikan peran terhadap kondisi afek positif individu. Individu yang bijaksana cenderung memiliki emosi dan perilaku positif. Adanya kemampuan refleksi diri juga menjadikan individu yang bijaksana memiliki simpati serta kasih sayang terhadap orang lain. Sebaliknya, individu yang bijaksana justru cenderung memiliki emosi dan perilaku negatif lebih sedikit daripada individu yang tidak bijaksana (Ardelt, 2003), sehingga apabila dikaitkan dengan perkembangan subjective well-being, wisdom dapat membuat seseorang memiliki tingkat subjective well-being yang tinggi. Subjek dalam penelitian ini memiliki kecenderungan masuk dalam kategori tinggi baik pada subjective well-being maupun wisdom-nya. Salah satu faktor yang berperan adalah tingkat pendidikan subjek yang cukup tinggi, yaitu sedang menempuh pendidikan sarjana. Pendidikan memerankan peran penting dalam perbedaan tingkat subjective wellbeing satu individu dengan individu lain (Binder, 2013), sedangkan wisdom perkembangannya sangat dipengaruhi oleh kecerdasan intelektual maupun emosi.
Pengalaman yang sudah dilalui subjek selama 20 tahun juga turut berperan dalam perkembangan wisdom maupun subjective well-being. Kehidupan sekolah maupun perguruan tinggi menawarkan berbagai kesempatan bergabung bersama organisasi, kepanitiaan maupun komunitas. Pengalaman yang didapatkan dalam berdinamika dengan banyak orang dapat mengasah kemampuan refleksi dan problem solving. Hal ini turut didukung dengan pernyataan Ardelt (2015) bahwa persepsi subjektif individu terhadap lingkungan serta kemampuannya untuk beradaptasi secara konstruktif dengan lingkungan dianggap lebih penting untuk menentukan bagaimana pengaruh lingkungan terhadap diri individu. Pendidikan, pengetahuan, dan pengalaman yang didapatkan oleh mahasiswa pada usia dewasa awal turut berkontribusi dalam kemampuannya mempersepsikan keadaan dan beradaptasi secara konstruktif dengan lingkungan.

Ardelt (2000) menyatakan bahwa seseorang yang telah memperoleh kebijaksanaan selama kehidupan akan mampu mencapai kepuasan hidup di masa tuanya. Individu yang bijaksana merasakan kepuasan dan pemenuhan hidup dalam kondisi apapun karena dapat menerima kehidupan seperti apa adanya dengan penuh penerimaan (Ardelt, 2000). Kepuasan dan adanya peneri-maan positif inilah yang mampu memberikan sumbangan kepada subjective well being.

\section{Kesimpulan}

Berdasarkan hasil penelitian yang telah dilakukan, ditemukan bahwa wisdom berperan positif terhadap subjective well-being pada dewasa awal. Semakin tinggi wisdom, maka semakin tinggi pula subjective well-being 
individu usia dewasa awal. Mayoritas subjek $(60,8 \%)$ menunjukkan wisdom yang tinggi, sedangkan subjective well-being antara sedang (59,5\%) hingga tinggi (20,3\%). Hasil ini menunjukkan bahwa individu usia dewasa awal sudah memiliki wisdom dan mereka mampu memaknai hidupnya, dan hal itu mengarahkan subjek pada subjective wellbeing yang tinggi.

\section{Saran}

Sesuai dengan tujuan yang dirumuskan pada awal penelitian, hasil dari penelitian ini diharapkan dapat menjadi informasi yang berguna bagi dasar pembuatan intervensi atau pelatihan bagi mahasiswa tingkat akhir untuk meningkatkan kemampuannya dalam memahami peristiwa dalam hidup secara lebih mendalam, menerima segala kekurangan maupun kelebihan yang dimilikinya, serta merasakan penilaian positif terhadap hidupnya.

Bagi peneliti selanjutnya disarankan untuk melalukan penelitian pada subjek dewasa awal dengan karakteristik yang lebih heterogen, misalnya dari latar belakang pendidikan, SES, dan tempat tinggal yang bervariasi. Hal ini bertujuan agar dapat memberikan gambaran kondisi individu dewasa awal dengan lebih menyeluruh. Selain itu, mengingat wisdom hanya menyumbang $10,8 \%$, peneliti selanjutnya diharapkan dapat meneliti variabel-variabel lain yang juga berhubungan dengan subjective well-being dan wisdom, seperti tipe kepribadian, life satisfaction, atau keterlibatan dalam kegiatan.

\section{Kepustakaan}

Andartyastuti, S., Maslihah, S., \& Chitidjah, S. (2015). Hubungan antara coping strategy dengan subjective well-being pekerja seks komersial di Kota
Bandung. Prosiding Seminar Nasional Penelitian dan PKM (SNaPP) Sosial, Ekonomi, dan Humaniora V(I) (pp. 677682). Bandung: UNISBA.

Ardelt, M. \& Edwards, C. A. (2015). Wisdom at the end of life: An analysis of mediating and moderating relations between wisdom and subjective wellbeing. Journals of Gerontology: Social Sciences, 1-12. doi: 10.1093/geronb/ gbv051

Ardelt, M. (2000). Antecedents and effects of wisdom in old age: A longitudinal perspective on aging well. Research on Aging, 7(4), 360-394. doi: 10.1177/ $\underline{0164027500224003}$

Ardelt, M. (2003). Empirical assessment of a three-dimensional wisdom scale. Research on Aging 25(3), 275-324. doi: 10.1177/0164027503251764

Ardelt, M. (2015). Disentangling the relations between wisdom and different types of well-being in old age: Findings from a short-term longitudinal study. Journal of Happiness Studies, 17(5), 1963-1984. doi: 10.1007/s10902-0159680-2

Arzeen, N., Haque, M. A., \& Arzeen, S. (2013). An investigation of relationship between wisdom and subjective well-being for a sample of Pakistani adolescents. FWU Journal of Social Science, 7(1), 39-46.

Badan Pusat Statistik. (2017, Mei 5). Berita resmi statistik. Retrieved from Badan Pusat Statistik: https://www.bps. go.id/website/brs ind/brsInd2017050 5104425.pdf

Binder, M. (2013). Innovativeness and subjective well-being. Social Indicators Research, 111(92), 561-578. doi: 10. 1007/s11205-012-0020-1 
Eddington, N., \& Shuman, R. (2005). Subjective well-being (happiness). Continuing Psychology Education, 1-18. Retrieved 01 25, 2017, from https://www.texcpe.com/html/pdf/ca La-happiness.pdf

Etezadi, S. \& Pushkar, D. (2013). Why are wise people happier? An explanatory model of wisdom and emotional well-being in older adult. Journal of Happiness Studies, 14, 929-950. doi: 10.1007/s10902-012-9362-2

Gunawati, R., Hartati, S., \& Listiara, A. (2006). Hubungan antara efektivitas komunikasi mahasiswa-dosen pembimbing utama skripsi dengan stress dalam menyusun skripsi pada mahasiswa Program Studi Psikologi Fakultas Kedokteran Universitas Diponegoro. Jurnal Psikologi Universitas Diponegoro, 3(2), 93-115. doi: 10.14710/jpu.3.2.93\%20-\%20115

Hyeyoung, B. (2013). African American undergraduate students' wisdom and ego-identity development: Effect of age, gender, self esteem, and resilience. Journal of Black Psychology 41(2), 95-120. doi: 10.1177/0095798 $\underline{413510176}$

Kholidah, E. N. \& Alsa, A. (2012). Berpikir positif untuk menurunkan stres psikologis. Jurnal Psikologi, 39(1), 6775. doi: 10.22146/jpsi.6967

Klassen, R. M., Krawchuck, L. K., \& Rajani, S. (2008). Academic procreastination of undergraduates: Low self-efficacy to self-regulate predicts higher levels of procrastination. Contemporary Educational Psychology, 33(2), 915-931. doi: 10.1016/j.cedpsych.2007.07.001

Lewis, C. A., Maltby, J., \& Day, L. (2005). Religius orientation, religious coping and happiness among UK adults. Personality and Individual Differences, 38,1193-1202. doi: 10.1016/j.paid.2004. $\underline{08.002}$

Mariyanti, S. (2013). Model strategi coping penyelesaian studi sebagai efek dari stresor serta implikasinya terhadap waktu penyelesaian studi mahasiswa Psikologi Universitas Esa Unggul. Jurnal Psikologi, 11(2), 66-73.

Reivich, K. \& Shatte, A. (2002). The resilience factor: 7 keys to finding your inner strength and overcome life's hurdles. New York: Broadway Books.

Richardson, M. J. \& Pasupathi, M. (2005). Young and growing wiser: Wisdom during adolescence and young adulthood. In M. J. Richardson, A Handbook of Wisdom: A Psychological Perspectives (pp. 139-159). New York: Cambridge University Press.

Rohmah, F. A. (2006). Efektifitas diskusi kelompok dan pelatihan efikasi diri untuk mengurangi stres pada mahasiswa yang sedang skripsi. Thesis, Yogyakarta: Fakultas Psikologi Universitas Gadjah Mada.

Santrock, J. W. (2014). A tropical approach to life-span development 7 th $E d$. New York: McGraw-Hill Education.

Staudinger, U. M., \& Pasupathi, M. (2003). Correlates of wisdom-related performance in adolescence and adulthood: Age-graded differences in "paths" toward desirable development. Journal of Research on Adolescence, 13, 239-268. doi: 10.1111/ 1532-7795.1303001

Utami, M. S. (2010). Skala kesejahteraan subjektif mahasiswa. Laporan Penelitian. Yogyakarta: Fakultas Psikologi UGM. 